\title{
Changing regional weather-crop yield relationships across Europe between 1901 and 2012
}

M. Trnka ${ }^{1,2, *}$, J. E. Olesen ${ }^{3}$, K. C. Kersebaum ${ }^{4}$, R. P. Rötter ${ }^{5,6}$, R. Brázdil ${ }^{1,7}$, J. Eitzinger ${ }^{8}$, S. Jansen ${ }^{9}$, A. O. Skjelvåg ${ }^{10}$, P. Peltonen-Sainio ${ }^{5}$, P. Hlavinka1 ${ }^{1}$ J. Balek ${ }^{1}$, H. Eckersten ${ }^{11}$, A. Gobin ${ }^{12}$, V. Vučeti ${ }^{13}$, A. Dalla Marta ${ }^{14}$, S. Orlandini ${ }^{14}$, V. Alexandrov ${ }^{15}$, D. Semerádová1,2, P. Štěpánek ${ }^{1}$, E. Svobodová1 ${ }^{1}$ K. Rajdl ${ }^{1}$

\footnotetext{
${ }^{1}$ Global Change Research Institute, Czech Academy of Sciences, Bĕlidla 986/4a, 60300 Brno, Czech Republic ${ }^{2}$ Institute of Agrosystems and Bioclimatology, Mendel University in Brno, Zemĕdĕlská 1, 61300 Brno, Czech Republic

${ }^{3}$ Department of Agroecology and Environment, Aarhus University, Blichers Allé 20, 8830 Tjele, Denmark

${ }^{4}$ Institute for Landscape Systems Analysis, Leibniz-Center of Agricultural Landscape Research, Eberswalder Str. 84, 15374 Müncheberg, Germany

${ }^{5}$ Natural Resources Institute Finland, Viikinkari 4, 00790 Helsinki, Finland

${ }^{6}$ Department of Crop Science, Georg-August-University, 37077 Göttingen, Germany

${ }^{7}$ Institute of Geography, Masaryk University, Kotlářská 2, 61137 Brno, Czech Republic
}

${ }^{8}$ Institute of Meteorology, University of Natural Resources and Life Sciences (BOKU), Peter-Jordan Str. 82, 1190 Vienna, Austria

${ }^{9}$ Alterra Wageningen UR, Alterra-Earth observation and environmental informatics group, PO Box 47, 6700AA Wageningen, The Netherlands

${ }^{10}$ Department of Plant and Environmental Sciences, Norwegian University of Life Sciences, PO Box 5003, 1432 Ås, Norway

${ }^{11}$ Department of Crop Production Ecology, Swedish University of Agricultural Sciences, Box 7043, 75007 Uppsala, Sweden

${ }^{12}$ Flemish Institute for Technological Research, Boeretang 200, 2400 Mol, Belgium

${ }^{13}$ Agrometeorological Department, Meteorological and Hydrological Service, Grič 3, 10000 Zagreb, Croatia

${ }^{14}$ Department of Agrifood Production and Environmental Sciences, University of Florence, Piazzale delle Cascine 18 , 50144 Firenze, Italy

${ }^{15}$ National Institute of Meteorology and Hydrology, Bulgarian Academy of Sciences, Tzarigradsko shose 66, 1784 Sofia, Bulgaria

ABSTRACT: Europe is, after Asia, the second largest producer of wheat in the world, and provides the largest share of barley. Wheat (and to a similar extent, barley) production in Europe increased by more than 6 -fold during the 20th century. During the first half of the 20th century, this was driven by expanding the harvested area. This was followed, from the mid-20th century, by a massive increase in productivity that in many regions has stalled since 2000. However, it remains unclear what role climatic factors have played in these changes. Understanding the net impact of climatic trends over the past century would also aid in our understanding of the potential impact of future climate changes and in assessments of the potential for adaptation across Europe. In this study, we compiled information from several sources on winter wheat and spring barley yields and climatological data from 12 countries/regions covering the period from 1901-2012. The studied area includes the majority of climatic regions in which wheat and barley are grown (from central Italy to Finland). We hypothesized that changes in climatic conditions have led to measurable shifts in climate-yield relationships over the past $112 \mathrm{yr}$, and that presently grown wheat and barley show a more pronounced response to adverse weather conditions compared to crops from the early $20^{\text {th }}$ century. The results confirm that climate-yield relationships have changed significantly over the period studied, and that in some regions, different predictors have had a greater effect on yields in recent times (between 1991 and 2012) than in previous decades. It is likely that changes in the climate-yield relationship at the local level might be more pronounced than those across the relatively large regions used in this study, as the latter represents aggregations of yields from various agroclimatic and pedoclimatic conditions that may show opposing trends.

KEY WORDS: Climatic trend - Weather-crop yield relationship $\cdot$ Wheat $\cdot$ Barley $\cdot$ Yield trend · Drought $\cdot$ Europe

${ }^{*}$ Corresponding author: mirek_trnka@yahoo.com
() The authors 2016. Open Access under Creative Commons by Attribution Licence. Use, distribution and reproduction are unrestricted. Authors and original publication must be credited. 


\section{INTRODUCTION}

Land management for food production is a fundamental human activity, supporting the lives of nearly everyone on this planet and providing livelihoods for a large part of the population. At present, more than 1.5 billion ha-approximately $12 \%$ of the world's land area - is used for crop production (FAO 2013). Wheat Triticum aestivum L., rice Oryza sativa L., maize Zea mays L., soybeans Glycine max (L.) Merr., barley Hordeum vulgare L. and sorghum Sorghum bicolor (L.) Moench. are the 6 most widely grown crops in the world. The production of these crops accounts for approximately $40 \%$ of global cropland area, $55 \%$ of non-meat calories and over $70 \%$ of animal feed (FAO 2006, 2013). Europe is a close second to Asia in global wheat production and provides the largest share of barley output. During the $20^{\text {th }}$ century, wheat (and to a similar extent barley) production increased in some European regions by more than 6 -fold (e.g. Slafer \& Rawson 1994). This increase was initially due to an expansion in harvested area that occurred during the first half of the century, which was followed from the 1950s onwards by an increase of ca. $150 \%$ in global mean yield per unit land area (Slafer \& Rawson 1996). For example, according to Slafer \& Peltonen-Sainio (2001), the relative increase in countries such as Canada, Denmark and Finland between the 1950s and the 1990s was up to $83 \%$ for barley and $131 \%$ for wheat. In northern Europe, significant increases in the share of wheat grown over the cultivated area have been reported; for example, Denmark showed an 8-fold increase between 1971 and 1997 (Olesen et al. 2000). In recent years there has been a stagnation in cereal yields in most parts of Europe, which has been attributed (at least in part) to changes in agricultural policies, input intensities and changes in climatic patterns (Brisson et al. 2010, Finger 2010, Ray et al. 2012)

Limitations due to climatic conditions play an important role in the geographical distribution of crop species in Europe (Ewert et al. 2005, Elsgaard et al. 2012). In Mediterranean countries, cereal yields are limited by water availability, heat stress and the short duration of the grain filling period, while under the continental climate of eastern Europe (eastwards from central Poland), drier conditions and greater fluctuations in annual temperature limit the range of crops that can be grown. The most productive regions in Europe in terms of climate and soils are located in the 'North European lowland plains', which were shaped by the most recent ice age, have a largely Atlantic temperate climate and stretch from south- east England through France, Benelux and Germany and into Poland. There are additional lowland regions (e.g. the Hungarian Plain) that also have quite favorable conditions for crops. From a global perspective, food supply security in Europe is likely to be less influenced by climate change than it may be in other regions because of technologically sophisticated agricultural practices (Brown \& Funk 2008), but climate-induced uncertainty (i.e. substantial fluctuations) in food production may result from elevated temperatures and associated changes in the frequency of adverse events in the future (e.g. Trnka et al. 2015). This agrees with the views of Lobell \& Burke (2008), and more recently with those of Porter et al. (2014), who proposed that research should focus on crop responses to elevated temperatures to assist in designing cropping systems that are resilient to the effects of global warming. While production for all crops has increased substantially since 1961, temperature and precipitation, spatially weighted for each crop, have also exhibited significant trends (Lobell \& Field 2007). For wheat, maize and barley, there is a clearly negative response of global yields to increased temperatures (Porter et al. 2014). Based on their sensitivity and the observed climatic trends, it has been estimated that warming since 1981 has resulted in an annual combined loss of these 3 crops representing approximately $40 \mathrm{Mt}$ (megatons), which represents $\$ 5$ billion $\mathrm{yr}^{-1}$ as of 2002 prices (Lobell \& Field 2007).

Many studies have considered the effects of past climate variability on agriculture (e.g. Calderini \& Slafer 1998, Lobell \& Field 2007, Finger 2010, Peltonen-Sainio et al. 2010, Lobell et al. 2011, Olesen et al. 2011). However, they have mainly focused on the most recent decades, for which yield and climatological data are relatively easy to obtain. They also relied only on national statistics due to the better availability of long-term datasets (e.g. Calderini \& Slafer 1998). Therefore, such studies generally do not consider crop-climate relationships prior to the recent warming that has occurred during the last 3 decades of the $20^{\text {th }}$ century. It is likely that warming (a global increase of $0.74^{\circ} \mathrm{C}$ between $1906-2005$, according to Solomon et al. 2007 ; or $0.85^{\circ} \mathrm{C}$ between 1880-2012, according to Stocker et al. 2013) has improved the agroclimatic conditions in many regions of Europe, and hence increased the yields of many crops, but it has also led to less favorable conditions and yield reductions in other regions (e.g. Trnka et al. 2011). It is also possible that such differences would more likely be found within relatively small regions than at a national level, which usually represent the aggregation of yields from various agrocli- 
matic and pedoclimatic conditions, as Trnka et al. (2012) showed in comparing the late $19^{\text {th }}$ century and contemporary district/county level yields in central Europe.

An understanding of the net global impact of climatic trends over the past century would aid in our understanding and quantitative assessment of the potential impact of future climate changes, and in determining future agricultural adaptive potentials. The major challenge in setting up 'historical' studies in Europe stems from the extensive changes that have occurred with respect to borders (both national and regional), state systems and inventory methodologies, which in some regions seriously affect the availability of yield data and to some extent that of climatological data. In addition, socio-economic crises, often caused or followed by wars, have had severe impacts on agricultural production and the productivity of crops. This study compiled several sources of data for 12 European countries/regions (see Fig. 1), aiming to collect the most complete datasets for the 1901-2012 period.

\section{DATA AND METHODS}

The regions studied are located along a northsouth transect of Europe and represent the area between $41^{\circ} 14^{\prime}-71^{\circ} 11^{\prime} \mathrm{N}$ and $2^{\circ} 33^{\prime}-31^{\circ} 35^{\prime} \mathrm{E}$ (see Fig. 1). The regions cover $1620847 \mathrm{~km}^{2}$ of land (representing $37 \%$ of the present area of the EU), $205866 \mathrm{~km}^{2}$ of which is arable, corresponding to $19 \%$ of the arable land in the EU (see Table 1). Regions were selected according to the following criteria: (1) comparable acreage of arable land (8400-37 $\left.200 \mathrm{~km}^{2}\right)_{i}(2)$ targeted crops (barley and wheat) are significant crops in terms of acreage, and are the most common cereal crops in the area; (3) little or no change in the administrative borders of the region during the 1901-2012 period; (4) availability of yield data.

The final selection included 10 countries and 2 regions at the sub-national level (Lower Saxony and Tuscany) (see Fig. 1, Table 1) that represent a broad range of climatic patterns, changing from warm and dry Mediterranean conditions (Tuscany, Croatia) or those of the Black Sea area (Bulgaria) through central Europe (Austria, Czech Republic) to the northern margins of agriculture in Europe (Norway, Finland). Some of the regions belong to traditional farming areas with high yields of both crops (The Netherlands, Belgium, Lower Saxony, Denmark), but other regions are in areas that are close to the northern (Norway, Finland) or southern (Tuscany, Bulgaria,
Croatia) extents of the growing areas for both crops in Europe. The final selection also included 3 'eastern' European countries, where production and productivity were enhanced through different mechanisms (former communist countries) than those used in their western counterparts between 1945 and 1990. The Czech Republic, Croatia and Bulgaria then experienced a period of transition to a free-market economy, which was achieved on joining the EU in 2000.

The monthly minimum, mean and maximum values for air temperature, precipitation, number of precipitation days and drought severity, expressed in terms of the Palmer Z-index and Palmer Drought Severity Index (Palmer 1965), were used as predictors of inter-annual yield variability (for a more detailed description of the Palmer Z-index, see Trnka et al. 2009). The monthly climatological data for each region were based on the CRU TS 3.21 dataset (released on 16 July 2013 at http://badc.nerc.ac.uk/ browse/badc/cru/data/cru_ts [note that the site requires that one resgisters before accessing the data]; for more details see Mitchell \& Jones 2005, Harris et al. 2014). Gridded data with a resolution of $0.5 \times 0.5$ degrees were based on mean monthly temperatures provided by $>4000$ weather stations around the world. Using this gridded data, a series of each climate variable was calculated for each region, using the proportion of arable land within the given grid and region as a weighting factor. For individual periods, the proportion of arable land within each grid was derived as the mean value for the given period using Global Cropland Data (1700-2007), which provides revised data described by Ramankutty \& Foley (1999) and is available at www.earthstat.org/data-download/. The final series of climate variables are provided in Supplement 1 at www.int-res.com/articles/ suppl/c070p195_supp/.

Originally, 6 crops were considered for analysis: wheat, barley, rye Secale cereale L., oat Avena sativa, potato Solanum tuberosum L. and sugar beet Beta vulgaris var. altissima. However, only wheat (particularly winter wheat) and barley (particularly spring barley) had sufficiently large acreage and yield data available in all regions during the periods analyzed. Therefore, they were selected for analysis in this study (see Supplement 2 at www.int-res.com/articles/ suppl/c070p195_supp/). The bulk of the data were provided by individual co-authors of the study from regionally available data, and these were confirmed - when possible - with supranational databases (particularly http://faostat3.fao.org/home/E and http://ec.europa.eu/eurostat/data/database). The final 
dataset used in the analysis is given in Supplement 2 . An extensive search of the relevant archives did not provide any further data for other periods beyond those analyzed in this paper. Although some of the European regions in this study went through significant changes in their borders and even their statehoods (e.g. Czech Republic, Austria or Croatia) during the period examined, the impact of these changes on the methodology of data collection were relatively small. In preparing the analysis, we aimed to select areas where yield data were thought to be available and where changes in regional borders were relatively minor during the $20^{\text {th }}$ century. However, in some cases data could not be obtained. For example, despite prolonged efforts, no yield data in the 1901-1920 period could be found for Tuscany or the Czech Republic. In addition, the war years from 1941-1945 were characterized by a higher number of missing data. Based on the analysis of break-points in the yield series, we defined 3 periods for which relationships between climatic variables and the yields of spring barley and winter wheat were studied: 1901-1950, 1951-1990 and 1991-2012.

Instead of using the annual means for each climatic variable, we defined a key period of the growing season during which barley and wheat are most sensitive to climatic variables. For both crops and the majority of the regions, we found that climatic patterns during April-June played a key role in determining yield, which is in agreement with results of Hlavinka et al. (2009) and Gobin (2012), as well as with the local knowledge of the authors of this study. As there was concern that conditions during July could significantly influence crop yields in cooler European regions (Kristensen et al. 2011), the initial analyses were made for all potential combinations; i.e. all months, all seasons and several month combinations (in total, 24 different time windows). The overall April-June period showed the most stable results with April-July or May-July being notably worse in the central and southern part of the evaluated region. The added value of using the April-July or May-July or June-July period for regions in the north of the regions compared to April-June was very limited and led to the same results. Therefore, the April-June period was selected to decrease the number of assumptions. However, for a consequent analysis (which is planned for those countries where the Nomenclature of Territorial Units for Statistics [NUTS 4] data will be available, at least in past decades) the effort will likely utilize a varying time window as one approach. To evaluate links between the yield series and climate, we always analyzed the relationships between deviations in the climate variables and the crop yields. We used 3 methods, which were based on (1) first order differences, (2) deviations from local means and (3) deviations from the trend curve.

(1) Approaches based on a first order difference series for yield and climatic variables (i.e. the difference from one year to the next) have been applied in a number of studies (e.g. Lobell \& Field 2007, Trnka et al. 2012). We transformed the first order differences of climatic variables and yields (yield estimates) into a $z$-score series using the mean and standard deviation of the period analyzed. We then performed multiple linear regressions, with the first order differences in yield (Yield) as the response variable and the first order differences in mean temperature (Tavg), maximum temperature (Tmax), minimum temperature (Tmin), precipitation totals (PREC), number of frost days (FRS), number of precipitation days (WetD), water vapor pressure deficit (VAP), potential evapotranspiration (PET), Palmer Z-index (ZIND) and Palmer Drought Severity Index (PDSI) as predictors.

(2) We also calculated deviations from the local mean yield (calculated as the difference from the 6 closest values in the database for the given region) which were transferred into $z$-scores, and $z$-scores of the particular climatic variable.

(3) When applying the approach based on the deviation from the trend curve, we used the difference from the trend line, or the $2^{\text {nd }}, 3^{\text {rd }}$ or $4^{\text {th }}$ order polynomial that fit to the line that best described the yield development. The difference was again transformed into $z$-scores and correlated with climatic variables.

As the results of all 3 approaches were not significantly different, we used the first order differences method as this is the simplest and requires a lower number of assumptions than the other two. In the preparation phase, other variables were also considered e.g. standardized precipitation index (SPI), standardized precipitation evapotranspiration index (SPEI) or amount of snow cover. However, in case of SPI and SPEI the results were similar to PREC and ZIND/ PDSI respectively, while monthly data based snow cover estimates did not correspond with observed daily data. Therefore we focused on the 10 straightforward climate predictors defined above.

The detrending method was used, as it is designed to minimize the influence of slowly changing factors, such as crop management techniques and farm technology, and allows for the examination of the seasonto-season (or season to long-term yield level) responses of yields to changes in the selected climatic variables. It was assumed that year-to-year manage- 
ment changes were not correlated with the climatic variables for the given year, but rather resulted from the experience gained in the previous years as a continuous process of learning from past mistakes throughout the time period analyzed in the paper. In addition, the division of the analysis period around 2 break-points, when yearly rate of yield changed markedly, allowed comparability over the whole analyzed period.

We also assumed that errors in a yield database were independent of climatic parameters. There were very significant shifts in the type of cereals being grown; rye was replaced by wheat, and oats by barley (e.g. Olesen et al. 2000). However, wheat and barley were among the 10 most commonly grown crops in most of the European regions throughout the study period. Therefore, they were assumed to always be present at sufficient acreage across the region of interest.

\section{RESULTS}

\subsection{Changing production levels}

The selected regions represent a climate gradient for the production of spring barley and winter wheat (Table 1, Fig. 1). They include regions with rather low annual and April-June temperatures that have either relatively dry (Finland or Sweden) or wet (Norway) spring and early summer conditions. Furthermore, the study included the highly productive areas of Lower Saxony, Denmark, Belgium and The Netherlands, as well as some regions with significant water limitations, such as in the Czech Republic, Austria and those more to the south in Tuscany and Bulgaria. As shown in Fig. 1d,e, climatic conditions between the periods of 1921-1940 and 19912010 changed considerably. All regions showed a significant increase in annual mean temperatures, which in some regions was even more pronounced from April-June. Annual precipitation totals either increased or remained the same, with the exception of Tuscany, which had a decrease in precipitation. The April-June precipitation levels markedly decreased in Bulgaria, Tuscany and Croatia and were notably increased in Norway, Sweden and Belgium. Fig. 1 shows that the 12 regions include not only the main crop producing areas but also regions with relatively low proportions of wheat and barley. The selected areas also represent a range of the environmental zones defined by Metzger et al. (2005) (Fig. 1a). In these regions, wheat and barley were

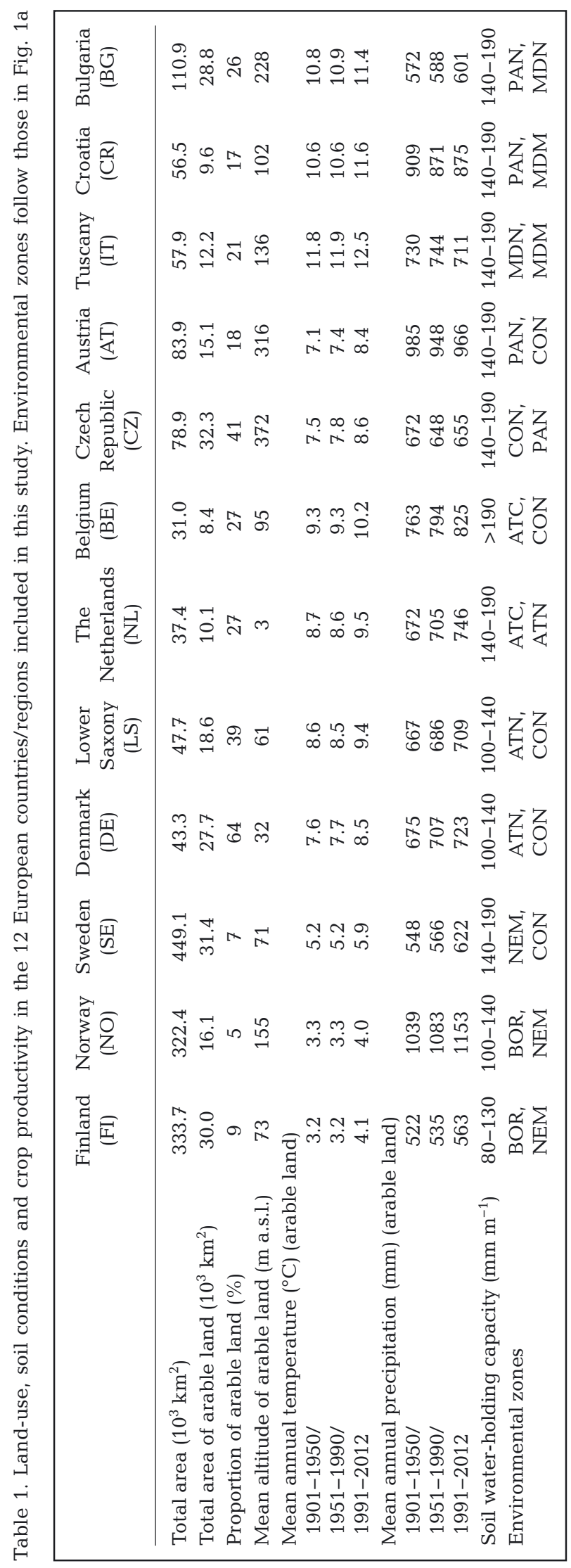






\begin{tabular}{|c|c|c|c|}
\hline \multicolumn{2}{|c|}{ Environmental zones } & ATC [ & Atlantic Central \\
\hline ALN & Alpine North & PAN & Pannonian \\
\hline BOR & Boreal & LUS [ & Lusitanian \\
\hline NEM & Nemoral & MDM [ & Mediterranean Moun tains \\
\hline ATN & Atlantic North & MDN [ & Mediterranean North \\
\hline ALS & Alpine South & $\operatorname{MDS}[$ & Mediterranean South \\
\hline CON & Continental & ANA [ & Anatolian \\
\hline
\end{tabular}
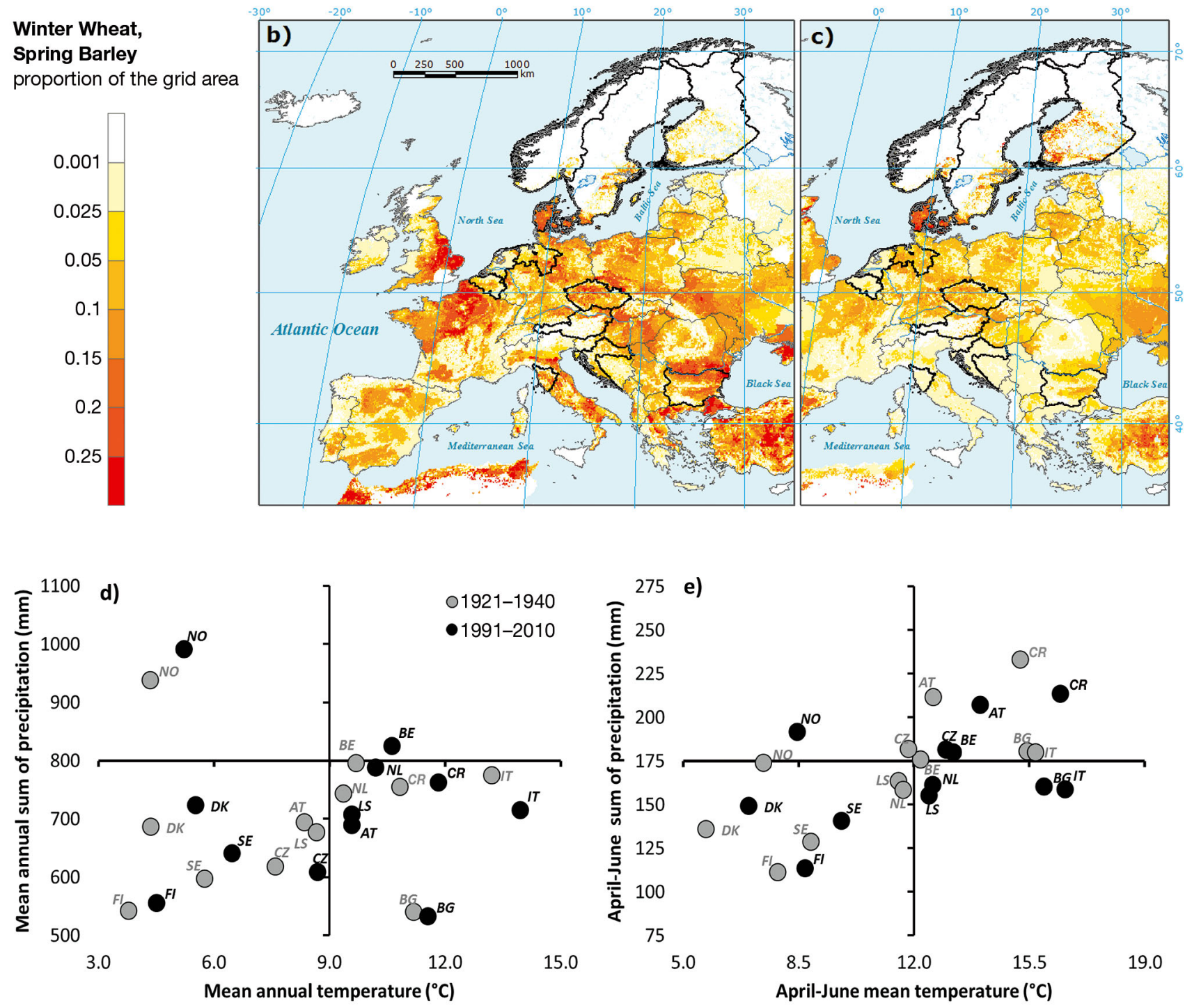

Fig. 1. (a) Main environmental zones in Europe, based on Metzger et al. (2005); (b) wheat and (c) barley growing areas in Europe, based on Monfreda et al. (2008), and the locations of the 12 countries/regions assessed in the study (thick borders). Mean (d) annual and (e) April-June temperature and precipitation for the 12 countries/regions (for abbreviations see Table 1) over the periods 1921-1940 and 1991-2010. Climatological data were weighted according to the proportion of arable land in each grid of the region 
mostly grown in the Atlantic North, Atlantic Central, Continental, Pannonian and Mediterranean (northern and mountainous regions) zones, but Nemoral and Boreal zones are also represented.

Table 1 and Supplement 2 show that the 1951-1990 and 1991-2012 periods are fairly well covered by yield data (with some exceptions for the 1950s in Sweden, Norway, Bulgaria and Austria). The 19011950 period has the worst coverage (see also Supplement 2), but with exception of Tuscany, each region is represented by at least $25 \mathrm{yr}$ of yield data. In the 1915-1919 and 1939-1948 periods, yields were affected by World Wars I and II and their aftermath. Especially in these years, data were missing for some countries (e.g. Austria, Czech Republic or Croatia) as yields were considered secret information. However, we included all available data even from these periods, because farmers would have strived to maximize production even during periods of war. Potentially disruptive events and major changes in the socio-economic structure of the society that could affect yield levels and overall agricultural practices are listed in Table 2 for each country. Rain was the source of water for virtually all of the cereal production during all periods analyzed.

Crop compositions and land allocation were comparable and did not differ by more than $1 / 3$ across all regions (Fig. 2e,f). Fig. 2 (based on Ramankutty \& Foley 1999) shows considerable changes in the proportion of arable land across Europe in the $20^{\text {th }}$ century. However, one of methodological aims of this study was to analyze primarily those regions where
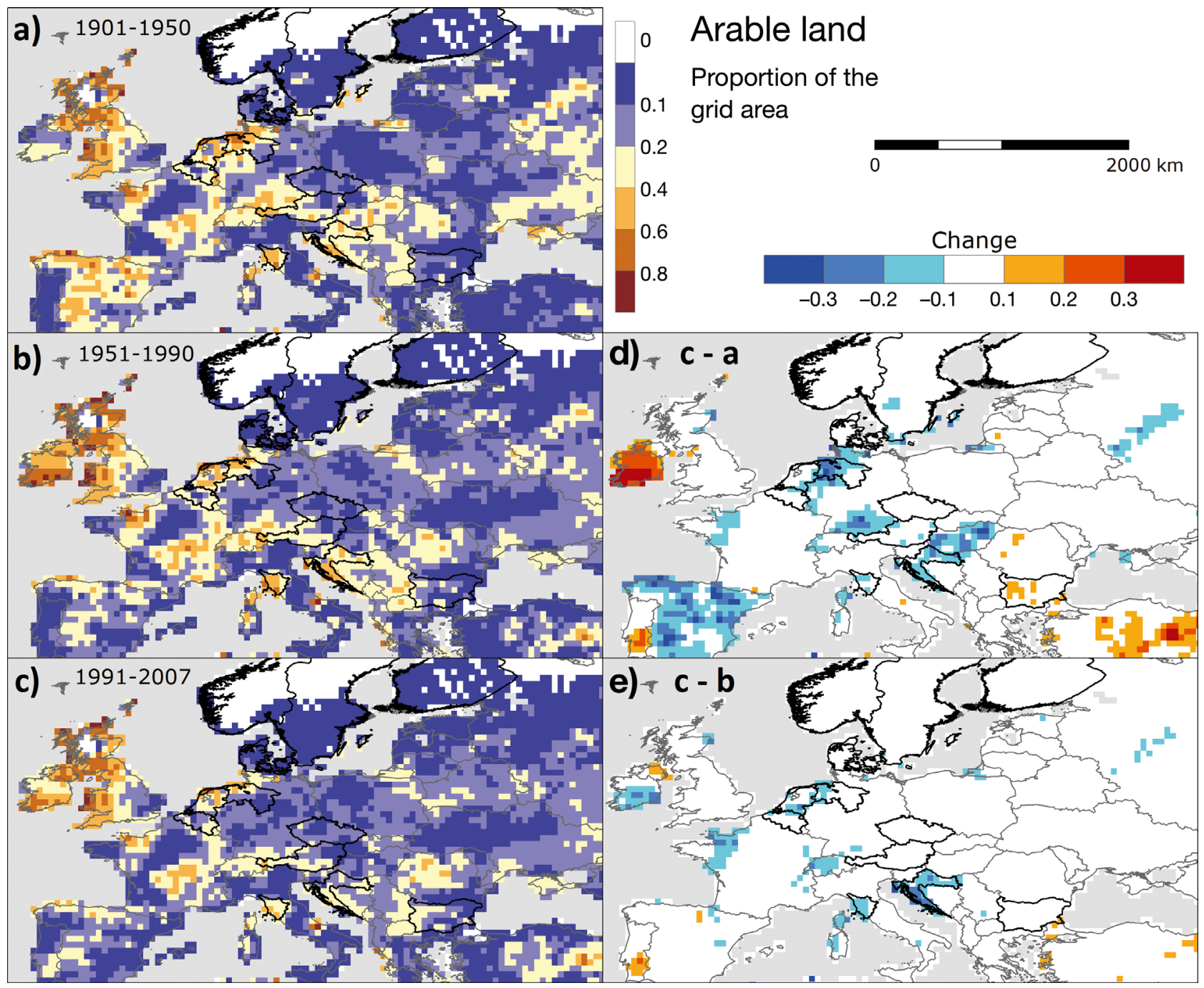

Fig. 2. Proportion of arable land based on the updated Ramankutty \& Foley (1999) study for the periods (a) 1901-1950, (b) 19511990 and (c) 1991-2007, and the differences between the periods (d) 1991-2007 and 1901-1950 and (e) 1991-2007 and 19511990. The 12 countries/regions considered in the study are indicated by thick borders 







\begin{tabular}{|c|c|c|c|c|c|}
\hline  & 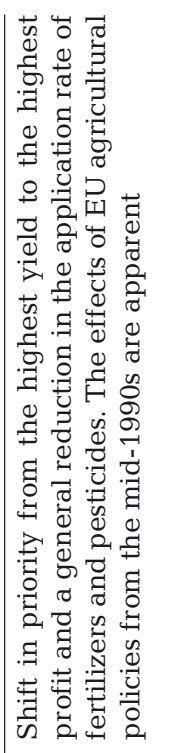 & 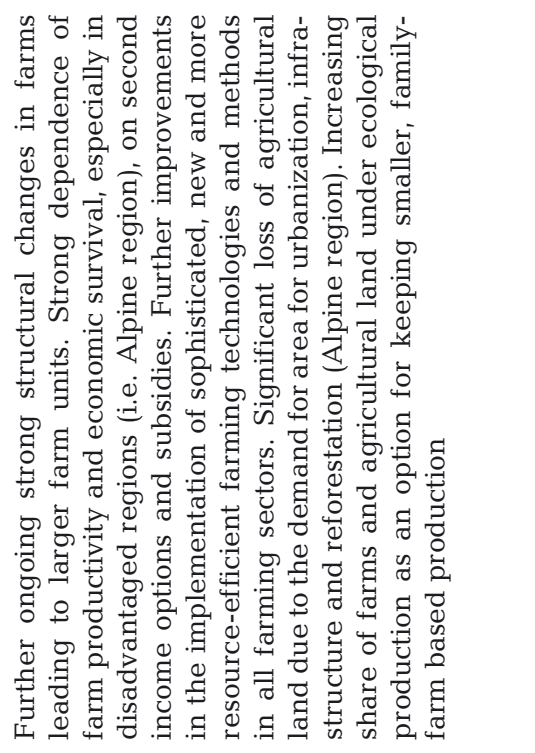 & 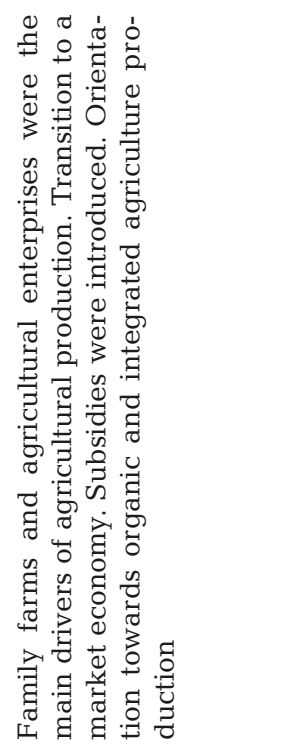 &  & 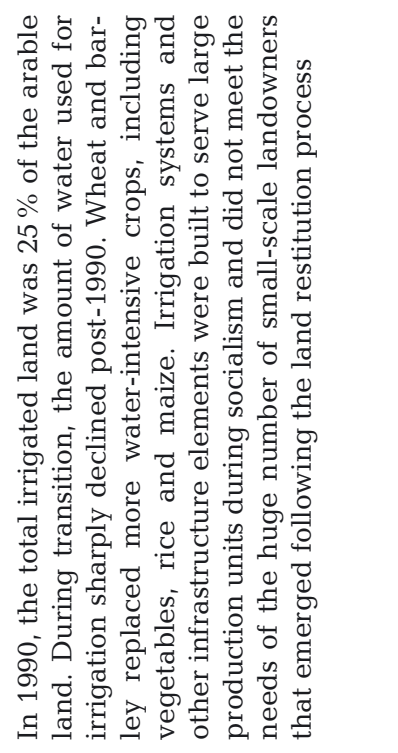 \\
\hline 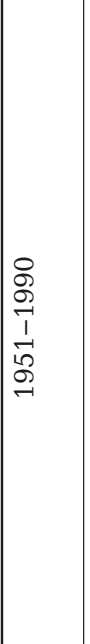 &  & 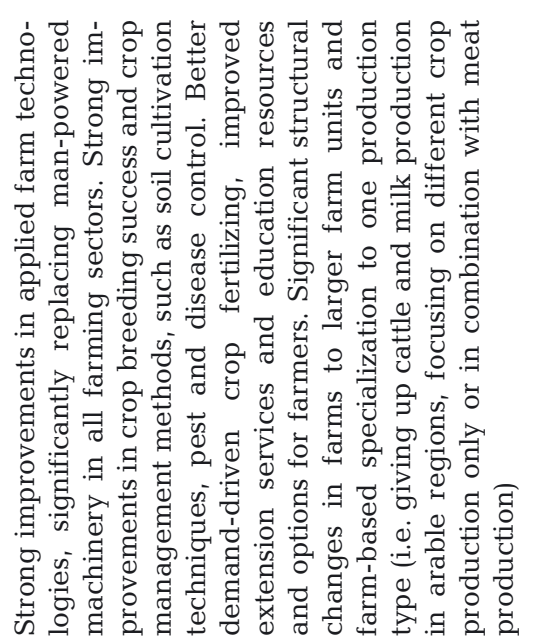 & 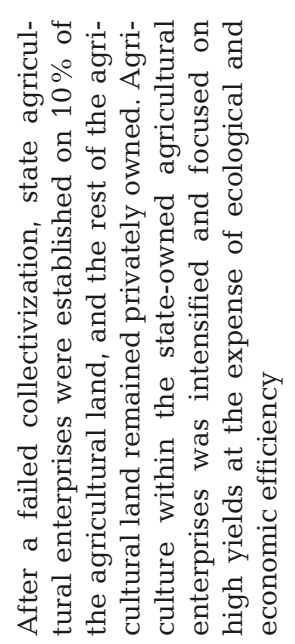 & 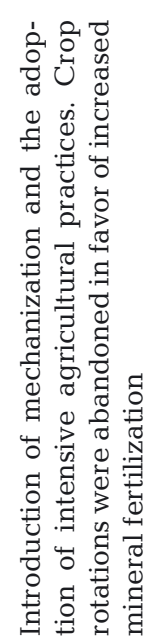 &  \\
\hline & 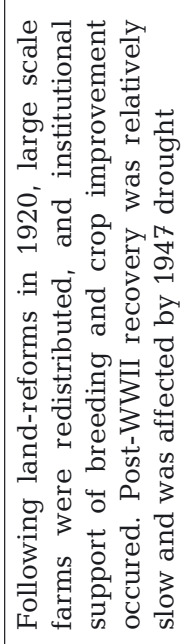 & 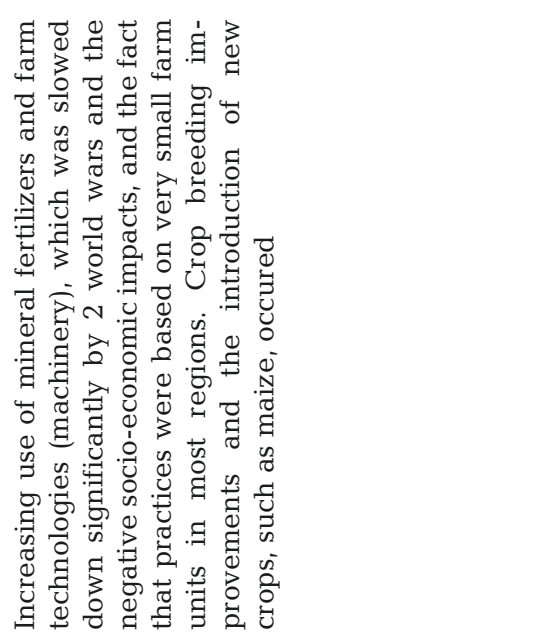 &  & 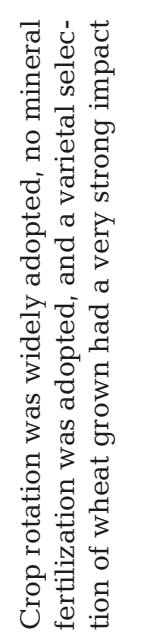 &  \\
\hline $0^{\circ}$ & U & 安 & 茗 & 巨 & $\infty$ \\
\hline
\end{tabular}


the changes in the proportion of arable land have been less pronounced. Fig. 2e,f shows that in most regions, the area of arable land has not changed considerably, with exception of Belgium, Croatia and Tuscany. Comparing 1991-2012 with 1901-1950, the decreases in arable land were between 10 and $20 \%$ in some areas within these 3 regions. These areas have been mainly converted to permanent grassland or, to a lesser extent, to forest. From 1991-2012, the proportion of arable land did not change dramatically in any of the evaluated regions when compared to the proportion in 1951-1990 (Fig. 2f). Fig. 2 allows for the analysis of changes in the weights assigned to the individual grids that were used to calculate the agroclimatic conditions within individual countries. These changes were rather small and were thus kept constant over the whole study period, with the distribution of the year 2000 being used. However, some changes were not covered by Ramankutty \& Foley (1999), as Table 2 shows for Lower Saxony.

\subsection{Yield trends}

Fig. 3 shows that the series of barley and wheat yields exhibited slow rates of increase until approximately the late 1940s, at which point the annual yield increased much faster and reached a plateau that has lasted since the 1990s.

The yield variability (when normalized by the mean yield level) did not differ significantly between periods. When data from all regions were pooled together there was a good agreement on the 'break-points' in the wheat and barley series. The period of slower annual yield growth ended in 1952 for barley and 2 yr later for wheat. The following period of rapid annual yield growth ended in 1989 and 1990 for wheat and barley, respectively. There are obvious and significant differences between individual regions with some having only one distinctive 'break-point' around early 1950s. However, a break-point analysis was used to select the following 3 distinctive periods for the subsequent analysis: 1901-1950, characterized by slower changes in annual yield; 1951-1990, showing rapid increase in annual yield; and 1991-2012, with a recent slow-down in changes in annual yield.

The large differences between the 3 selected periods are well depicted in Fig. 3a,b. In the most recent period (1991-2012), we can distinguish 3 groups of regions. (1) The 3 Nordic countries (Finland, Norway, Sweden) had generally lower yields than other regions and smaller yield increments relative to those from the 1951-1990 period, and even relative to those from 1901-1950 period. (2) Comparable results were found for the central and southern European regions (Czech Republic, Austria, Croatia, Tuscany, Bulgaria), where yields of barley were similar to those of the Nordic countries, but wheat yields were markedly higher. This partly follows from differences in soil conditions, i.e. the often sandy (relatively poor in nitrogen and phosphorous) or relatively shallow or water-logged soil profiles in some Nordic countries compared to the generally deeper and more fertile soils in central (Austria and Czech Republic) and southern (Tuscany, Bulgaria) Europe. Wheat is primarily grown on better soils due to its generally higher yields. (3) The third group is represented by Denmark, Lower Saxony, The Netherlands and Belgium, where wheat yields in particular were much higher than in the other regions and the yield differences between the 1991-2012 and 1951-1990 periods were the greatest, primarily due to favorable climatic conditions. In addition, apart from climatic factors, high yields could be to some extent attributed to (i) surplus manure stemming from high livestock densities, (ii) relative land scarcity due to high population pressures encouraging higher and more costefficient investments in farm infrastructure (particularly in Belgium and The Netherlands), (iii) past investment into agricultural research and development and (iv) more homogeneous terrain in the northwestern/central countries than in the Nordic ones or those in the central/southern regions.

\subsection{Climatic effects on wheat yields}

\subsubsection{Individual climatic parameters}

Only negative associations were established between first order differences of annual wheat yields and selected climatic parameters (Table 3). In the case of minimum temperatures and water vapor pressure deficits there was a significant (yet weak) relationship across all 3 periods. Yields across all regions and over the whole period responded significantly to all parameters, with the exception of potential evapotranspiration - which is not surprising as actual evapotranspiration would be a better indicator of water availability. Overall, inter-annual climatic variations explained only a small fraction of the wheat yield variations when they were considered separately. At the level of the individual regions, individual climatic parameters tended to explain a greater proportion of the year-to-year yield variations. Total precipitation explained up to $60 \%$ of the year-to-year yield vari- 



Fig. 3. Distribution of (a) barley and (b) wheat yields expressed as box-plots for the countries/regions included in the study for the 1901-1950, 1951-1990 and 1991-2012 periods. (c,d) Inter-annual variability of normalized yields for (c) barley and (d) wheat in all countries/regions with 'break' lines

ability in Belgium, The Netherlands and Lower Saxony, and a similar response was found across all 3 periods studied. On the other hand, temperaturerelated characteristics had a better predictive value for both the Nordic countries and those below $50^{\circ} \mathrm{N}$ latitude. However, temperature variations were unable to explain $>1 / 3$ (and usually much less) of the inter-annual variability. The number of statistically 


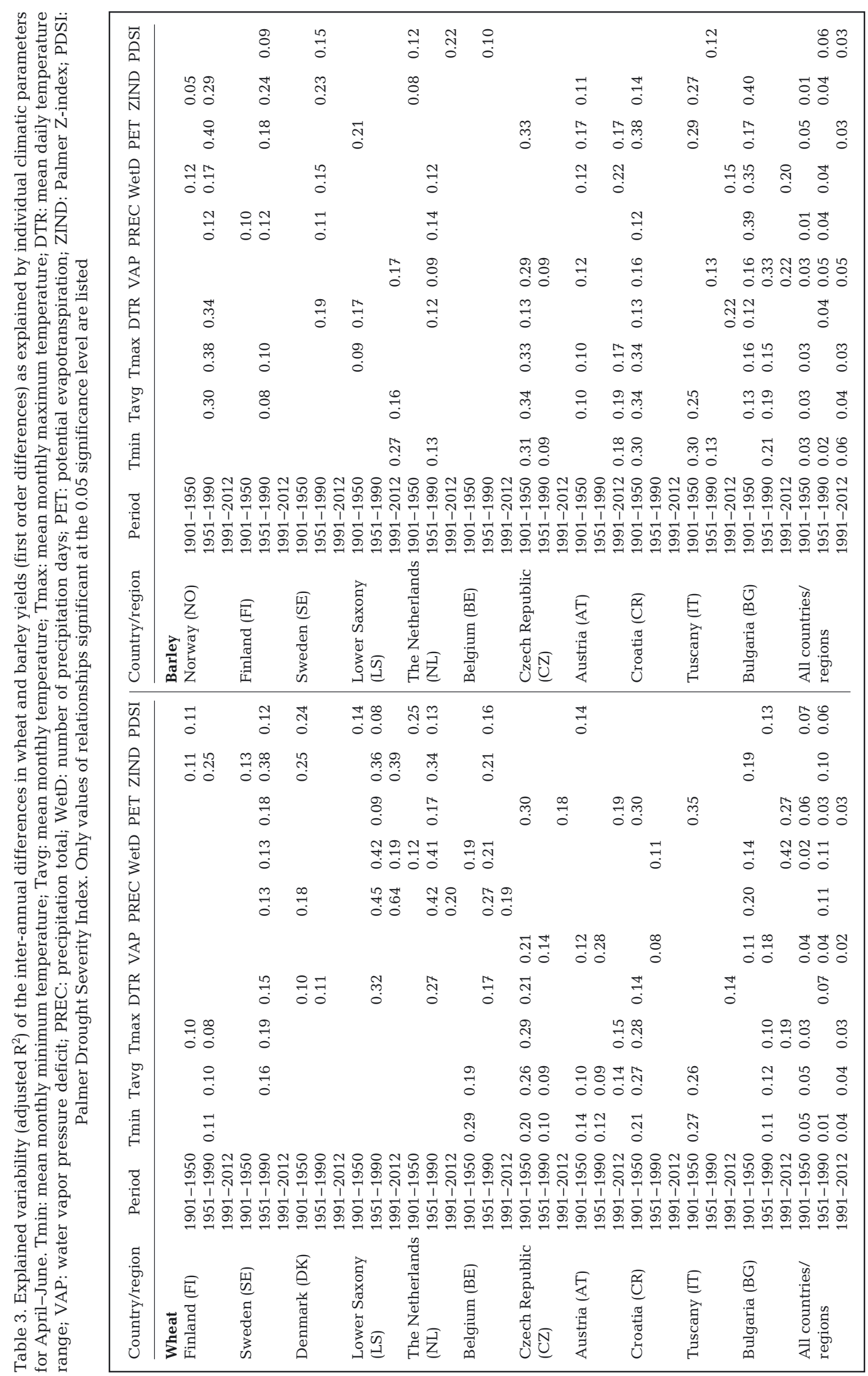


significant relationships between climatic variables and annual yield changed over the individual periods. The number was broadly similar for the first 2 periods, but the ability of inter-annual climatic variations in single parameters to explain yield variability sharply decreased for the 1991-2012 period.

\subsubsection{Combined climatic factors}

Table 4 indicates that even combining the selected pool of climatic variables for April-June did not explain a large portion of the year-to-year variability in wheat yield between 1901 and 2012, but this also differs strongly by region. Even in the regions where a larger portion of the annual yield variability was explained by climatic factors (e.g. Sweden and Belgium), the mean absolute error (MAE) and root mean square error (RMSE) values indicated that even these relationships were not useful for yield prediction. However, precipitation, number of frost days and other parameters related to temperature seemed to be essential for explaining yield variability, while this was not the case for drought indicators. In general, precipitation totals played a negative role determining yield variations; i.e. year-to-year increases in precipitation totals suggested a decline in yield, which was also generally the case for Tmax.

For wheat, we recorded only a small number of cases when the relationship with climatic variables changed markedly with the time period (Table 5). It is, however, worth noting that such changes were recorded in Finland and Bulgaria (i.e. in the northern and southeastern end of the area studied). However, climatic variables that were able to explain a reasonable amount of yield variability from 1991-2012 in these 2 countries failed (or showed a much lower capacity) to do so from 1901-1950. This tendency

Table 4. Explained variability (adjusted $\mathrm{R}^{2}$ ), relative mean absolute error (MAE) and root mean square error (RMSE) of the interannual differences in wheat and barley yield (first order differences) as explained by a combination of climatic parameters for April-June in the period 1901-2012 in the individual European countries/regions. Tavg: mean monthly temperature; Tmin: mean monthly minimum temperature; Tmax: mean monthly maximum temperature; DTR: mean daily temperature range; FRS: number of frost days; PREC: precipitation total; WetD: number of precipitation days; VAP: water vapor pressure deficit; PET: potential evapotranspiration; ZIND: Palmer Z-index; PDSI: Palmer Drought Severity Index. X (Y) identifies significant contributors at the 0.1 significance level, $\mathrm{x}(\mathrm{y})$ : non-significant contributors. $\mathrm{X}(\mathrm{x})$ : yield increases with an increasing value of the climatic parameter, Y (y): the opposite relationship. The significance of the single variables should be interpreted with caution as the predictors are mutually correlated, e.g. when Tavg is significant and Tmax is not, the significance of Tmax is probably only 'hidden' by the multicollinearity

$\mathrm{R}_{\text {adj }}^{2}$ MAE (\%) RMSE (\%) Tavg Tmin Tmax DTR FRS PREC WetD VAP PET ZIND PDSI

\begin{tabular}{|c|c|c|c|c|c|c|c|c|c|c|c|c|c|c|}
\hline \multicolumn{15}{|l|}{ Wheat } \\
\hline Finland (FI) & 0.05 & 96 & 134 & & y & y & $\mathrm{y}$ & $\mathrm{y}$ & & & $\mathrm{Y}$ & $\mathrm{Y}$ & & \\
\hline Sweden (SE) & 0.41 & 77 & 97 & & $\mathrm{Y}$ & & & & $\mathrm{Y}$ & & & & $\mathrm{Y}$ & \\
\hline Denmark (DK) & 0.20 & 86 & 112 & & & $\mathrm{Y}$ & $\mathrm{Y}$ & $\mathrm{Y}$ & & $\mathrm{y}$ & & $\mathrm{y}$ & & \\
\hline Lower Saxony (LS) & 0.34 & 85 & 105 & y & & & & $\mathrm{y}$ & $\mathrm{Y}$ & & & & & \\
\hline The Netherlands (NL) & 0.21 & 89 & 111 & y & $\mathrm{Y}$ & & $\mathrm{y}$ & $\mathrm{y}$ & & & & & & \\
\hline Belgium (BE) & 0.40 & 74 & 93 & $\mathrm{Y}$ & $\mathrm{Y}$ & $\mathrm{Y}$ & & $\mathrm{Y}$ & $\mathrm{Y}$ & & & & $\mathrm{Y}$ & $\mathrm{y}$ \\
\hline Czech Republic (CZ) & 0.20 & 89 & 115 & & & & & & $\mathrm{Y}$ & & & $\mathrm{Y}$ & & \\
\hline Austria (AT) & 0.16 & 90 & 127 & & & $\mathrm{Y}$ & $\mathrm{Y}$ & $\mathrm{Y}$ & $\mathrm{Y}$ & & $\mathrm{y}$ & & & $\mathrm{y}$ \\
\hline Croatia (CR) & 0.06 & 93 & 122 & $\mathrm{Y}$ & $\mathrm{Y}$ & & $\mathrm{Y}$ & $\mathrm{y}$ & & & $\mathrm{y}$ & $\mathrm{y}$ & & \\
\hline Tuscany (IT) & 0.25 & 87 & 108 & & & & & $\mathrm{Y}$ & $\mathrm{Y}$ & $\mathrm{Y}$ & & & $\mathrm{Y}$ & $\mathrm{Y}$ \\
\hline Bulgaria (BG) & 0.31 & 90 & 117 & & & & & & $\mathrm{Y}$ & $\mathrm{Y}$ & $\mathrm{y}$ & & $\mathrm{Y}$ & $\mathrm{y}$ \\
\hline All countries/regions & 0.13 & 94 & 125 & & & $\mathrm{Y}$ & $\mathrm{Y}$ & $\mathrm{Y}$ & $\mathrm{Y}$ & & & & & \\
\hline \multicolumn{15}{|l|}{ Barley } \\
\hline \multicolumn{15}{|l|}{ Finland (FI) } \\
\hline Norway (NO) & 0.05 & 96 & 127 & $\mathrm{y}$ & & $\mathrm{x}$ & $\mathrm{y}$ & & & & & & & \\
\hline Sweden (SE) & 0.28 & 82 & 108 & & y & $\mathrm{x}$ & $\mathrm{y}$ & $\mathrm{Y}$ & $\mathrm{X}$ & & $\mathrm{x}$ & & $\mathrm{Y}$ & \\
\hline Lower Saxony (LS) & 0.09 & 94 & 121 & $\mathrm{x}$ & $\mathrm{y}$ & & & & & $\mathrm{x}$ & & $\mathrm{y}$ & $\mathrm{y}$ & \\
\hline The Netherlands (NL) & 0.24 & 83 & 107 & $\mathrm{X}$ & & $\mathrm{Y}$ & $\mathrm{X}$ & & $\mathrm{y}$ & & & & $\mathrm{x}$ & $\mathrm{Y}$ \\
\hline Belgium (BE) & 0.15 & 88 & 121 & & & & & & $\mathrm{Y}$ & & & & $\mathrm{X}$ & $\mathrm{Y}$ \\
\hline Czech Republic (CZ) & 0.20 & 88 & 115 & & $\mathrm{Y}$ & & & $\mathrm{Y}$ & & & & & & \\
\hline Austria (AT) & 0.19 & 95 & 126 & $\mathrm{X}$ & & $\mathrm{Y}$ & $\mathrm{X}$ & & $\mathrm{y}$ & & & $\mathrm{Y}$ & $\mathrm{x}$ & \\
\hline Croatia (CR) & 0.17 & 91 & 114 & & & & & $\mathrm{y}$ & $\mathrm{Y}$ & & & & $\mathrm{X}$ & $\mathrm{Y}$ \\
\hline Tuscany (IT) & 0.07 & 98 & 139 & & $\mathrm{x}$ & y & $\mathrm{x}$ & $\mathrm{Y}$ & & & & & & \\
\hline Bulgaria (BG) & 0.27 & 89 & 111 & & $\mathrm{X}$ & $\mathrm{Y}$ & $\mathrm{X}$ & & $\mathrm{Y}$ & & & & $\mathrm{X}$ & $\mathrm{Y}$ \\
\hline All countries/regions & 0.10 & 95 & 128 & & & $\mathrm{Y}$ & $\mathrm{X}$ & $\mathrm{Y}$ & $\mathrm{Y}$ & & & & & \\
\hline
\end{tabular}


Table 5. As Table 4 for 3 different periods (1901-1950, 1951-1990, 1991-2012). Only those parameters significant at the 0.05 significance level during the 1991-2012 period are listed

\begin{tabular}{|c|c|c|c|c|c|c|c|c|c|c|c|c|c|c|c|}
\hline Country/region & Period & $\mathrm{R}_{\text {adj }}^{2}$ & $\begin{array}{c}\text { MAE } \\
(\%)\end{array}$ & $\begin{array}{c}\text { RMSE } \\
(\%)\end{array}$ & Tavg & Tmin & Tmax & DTR & FRS & PREC & WetD & VAP & PET & ZIND & PDSI \\
\hline \multicolumn{16}{|l|}{ Wheat } \\
\hline \multirow{3}{*}{ Finland (FI) } & 1901-1950 & 0.01 & 99 & 130 & & $\mathrm{y}$ & $\mathrm{x}$ & $\mathrm{y}$ & y & & & $\mathrm{y}$ & y & & \\
\hline & 1951-1990 & 0.20 & 88 & 110 & & $\mathrm{X}$ & $\mathrm{Y}$ & $\mathrm{X}$ & $\mathrm{x}$ & & & $\mathrm{Y}$ & $\mathrm{y}$ & & \\
\hline & 1991-2012 & 0.24 & 81 & 98 & & $\mathrm{X}$ & $\mathrm{Y}$ & $\mathrm{X}$ & $\mathrm{Y}$ & & & $\mathrm{X}$ & $\mathrm{X}$ & & \\
\hline \multirow[t]{3}{*}{ Sweden (SE) } & 1901-1950 & 0.51 & 71 & 92 & & $\mathrm{Y}$ & & & & $\mathrm{X}$ & & & & $\mathrm{Y}$ & \\
\hline & 1951-1990 & 0.51 & 62 & 78 & & $\mathrm{y}$ & & & & $\mathrm{X}$ & & & & $\mathrm{Y}$ & \\
\hline & 1991-2012 & 0.18 & 90 & 101 & & $\mathrm{Y}$ & & & & $\mathrm{X}$ & & & & $\mathrm{Y}$ & \\
\hline \multirow[t]{3}{*}{ Denmark (DK) } & 1901-1950 & 0.35 & 82 & 96 & & & $\mathrm{Y}$ & $\mathrm{X}$ & $\mathrm{Y}$ & & $\mathrm{x}$ & & $\mathrm{X}$ & & \\
\hline & 1951-1990 & 0.06 & 78 & 108 & & & $\mathrm{y}$ & $\mathrm{x}$ & $\mathrm{y}$ & & $\mathrm{x}$ & & $\mathrm{x}$ & & \\
\hline & 1991-2012 & 0.25 & 71 & 99 & & & $\mathrm{Y}$ & $\mathrm{X}$ & $\mathrm{Y}$ & & $\mathrm{X}$ & & $\mathrm{X}$ & & \\
\hline & 1901-1950 & 0.13 & 91 & 109 & $\mathrm{Y}$ & & & & $\mathrm{y}$ & $\mathrm{Y}$ & & & & & \\
\hline \multirow{2}{*}{ (LS) } & $1951-1990$ & 0.50 & 64 & 81 & $\mathrm{x}$ & & & & $\mathrm{X}$ & $\mathrm{Y}$ & & & & & \\
\hline & 1991-2012 & 0.71 & 51 & 65 & $\mathrm{Y}$ & & & & $\mathrm{Y}$ & $\mathrm{Y}$ & & & & & \\
\hline The Nether- & 1901-1950 & 0.32 & 80 & 101 & $\mathrm{y}$ & $\mathrm{x}$ & & $\mathrm{x}$ & $\mathrm{y}$ & & & & & & \\
\hline \multirow{2}{*}{ lands (NL) } & $1951-1990$ & 0.24 & 81 & 104 & $\mathrm{x}$ & $\mathrm{y}$ & & $\mathrm{y}$ & $\mathrm{x}$ & & & & & & \\
\hline & 1991-2012 & 0.29 & 75 & 94 & $\mathrm{X}$ & $\mathrm{Y}$ & & $\mathrm{Y}$ & $\mathrm{Y}$ & & & & & & \\
\hline \multirow[t]{3}{*}{ Belgium (BE) } & 1901-1950 & 0.43 & 66 & 85 & $\mathrm{X}$ & $\mathrm{Y}$ & $\mathrm{Y}$ & & $\mathrm{Y}$ & $\mathrm{x}$ & & & & y & $\mathrm{Y}$ \\
\hline & 1951-1990 & 0.52 & 58 & 76 & $\mathrm{x}$ & y & y & & y & $\mathrm{Y}$ & & & & $\mathrm{X}$ & $\mathrm{Y}$ \\
\hline & 1991-2012 & 0.59 & 57 & 66 & $\mathrm{X}$ & $\mathrm{Y}$ & $\mathrm{Y}$ & & $\mathrm{Y}$ & $\mathrm{Y}$ & & & & $\mathrm{X}$ & $\mathrm{Y}$ \\
\hline Czech & 1901-1950 & 0.33 & 80 & 96 & & & & & & $\mathrm{y}$ & & & $\mathrm{Y}$ & & \\
\hline \multirow[t]{2}{*}{ Republic (CZ) } & 1951-1990 & 0.04 & 98 & 118 & & & & & & $\mathrm{y}$ & & & $\mathrm{Y}$ & & \\
\hline & 1991-2012 & 0.34 & 70 & 95 & & & & & & $\mathrm{Y}$ & & & $\mathrm{Y}$ & & \\
\hline \multirow[t]{3}{*}{ Austria (AT) } & 1901-1950 & 0.27 & 72 & 92 & & & $\mathrm{y}$ & $\mathrm{X}$ & $\mathrm{y}$ & $\mathrm{y}$ & & $\mathrm{x}$ & & & $\mathrm{Y}$ \\
\hline & 1951-1990 & 0.40 & 73 & 89 & & & $\mathrm{y}$ & $\mathrm{x}$ & $\mathrm{y}$ & $\mathrm{y}$ & & $\mathrm{Y}$ & & & $\mathrm{Y}$ \\
\hline & 1991-2012 & 0.49 & 69 & 79 & & & $\mathrm{Y}$ & $\mathrm{X}$ & $\mathrm{Y}$ & $\mathrm{Y}$ & & $\mathrm{X}$ & & & $\mathrm{X}$ \\
\hline \multirow[t]{3}{*}{ Croatia (CR) } & 1901-1950 & 0.32 & 55 & 70 & $\mathrm{y}$ & $\mathrm{x}$ & & $\mathrm{x}$ & $\mathrm{x}$ & & & y & y & & \\
\hline & 1951-1990 & 0.01 & 86 & 109 & $\mathrm{x}$ & $\mathrm{y}$ & & $\mathrm{y}$ & $\mathrm{y}$ & & & $\mathrm{y}$ & y & & \\
\hline & 1991-2012 & 0.62 & 61 & 74 & $\mathrm{Y}$ & $\mathrm{X}$ & & $\mathrm{X}$ & $\mathrm{Y}$ & & & $\mathrm{Y}$ & $\mathrm{Y}$ & & \\
\hline \multirow[t]{3}{*}{ Tuscany (IT) } & 1901-1950 & 0.36 & 65 & 87 & & & & & $\mathrm{x}$ & y & y & & & $\mathrm{X}$ & $\mathrm{Y}$ \\
\hline & 1951-1990 & 0.31 & 75 & 94 & & & & & $\mathrm{Y}$ & $\mathrm{Y}$ & $\mathrm{Y}$ & & & $\mathrm{X}$ & $\mathrm{Y}$ \\
\hline & $1991-2012$ & 0.47 & 69 & 79 & & & & & $\mathrm{Y}$ & $\mathrm{Y}$ & $\mathrm{Y}$ & & & $\mathrm{X}$ & $\mathrm{Y}$ \\
\hline \multirow[t]{3}{*}{ Bulgaria (BG) } & 1901-1950 & 0.15 & 75 & 101 & & & & & & $\mathrm{x}$ & $\mathrm{x}$ & $\mathrm{y}$ & & $\mathrm{y}$ & $\mathrm{X}$ \\
\hline & 1951-1990 & 0.44 & 72 & 92 & & & & & & $\mathrm{Y}$ & $\mathrm{X}$ & y & & $\mathrm{x}$ & $\mathrm{X}$ \\
\hline & 1991-2012 & 0.61 & 58 & 75 & & & & & & $\mathrm{Y}$ & $\mathrm{X}$ & $\mathrm{X}$ & & $\mathrm{X}$ & $\mathrm{Y}$ \\
\hline \multirow{3}{*}{$\begin{array}{l}\text { All countries/ } \\
\text { regions }\end{array}$} & $1901-1950$ & 0.16 & 91 & 120 & & & $\mathrm{Y}$ & $\mathrm{X}$ & $\mathrm{Y}$ & $\mathrm{Y}$ & & & & & \\
\hline & 1951-1990 & 0.16 & 90 & 117 & & & $\mathrm{Y}$ & $\mathrm{X}$ & $\mathrm{Y}$ & $\mathrm{Y}$ & & & & & \\
\hline & 1991-2012 & 0.17 & 95 & 118 & & & $\mathrm{Y}$ & $\mathrm{X}$ & $\mathrm{Y}$ & $\mathrm{Y}$ & \multicolumn{5}{|c|}{ (Table continued on next page) } \\
\hline
\end{tabular}

was also found for Lower Saxony. However, in the rest of the countries, the explained variability did not change to any great extent. While one would expect the most variability to be explained by the regression analysis of the data from 1991-2012 (as climatic variables were selected using these data), this was not the case, and 4 of the 11 regions showed that a higher or much higher proportion of the variability was explained in the earlier periods. Fig. 4a shows that the adjusted $\mathrm{R}^{2}$ (i.e. the explained variability) was higher and the relative RMSE was lower for the period from 1991-2012 than for 1901-1950 and 1951-1990. This indicates that factors affecting yield variability indeed changed over time, although this change must have been relatively subtle.

\subsection{Climatic effects on barley yields}

\subsubsection{Individual climatic parameters}

The first order differences of the selected climatic parameters for barley (Table 3) were, in general, poor predictors of yield change. Only minimum temperatures and water vapor pressure deficits showed significant (yet weak) relationships across all 3 periods. Yields across all regions and the whole period studied responded significantly to all parameters, with the exception of potential evapotranspiration - but as observed for wheat, only an insignificant fraction of yield variation was explained by the variation of individual climatic indicators. While a larger portion of yield variation was explained for individual re- 
Table 5 (continued)

\begin{tabular}{|c|c|c|c|c|c|c|c|c|c|c|c|c|c|c|c|}
\hline Country/region & Period & $\mathrm{R}_{\text {adj }}^{2}$ & $\begin{array}{c}\text { MAE } \\
(\%)\end{array}$ & $\begin{array}{c}\text { RMSE } \\
(\%)\end{array}$ & Tavg & Tmin & Tmax & DTR & FRS & PREC & WetD & VAP & PET & ZIND & PDSI \\
\hline \multicolumn{16}{|l|}{ Barley } \\
\hline \multirow[t]{3}{*}{ Finland (FI) } & $1901-1950$ & & & & & & & & & & & & & & \\
\hline & $1951-1990$ & & & & & & & & & & & & & & \\
\hline & $1991-2012$ & & & & & & & & & & & & & & \\
\hline \multirow[t]{3}{*}{ Norway (NO) } & $1901-1950$ & 0.00 & 94 & 113 & $\mathrm{x}$ & & $\mathrm{y}$ & $\mathrm{x}$ & & & & & & & \\
\hline & $1951-1990$ & 0.48 & 64 & 80 & $\mathrm{X}$ & & $\mathrm{Y}$ & $\mathrm{X}$ & & & & & & & \\
\hline & $1991-2012$ & 0.05 & 88 & 123 & $\mathrm{Y}$ & & $\mathrm{X}$ & $\mathrm{Y}$ & & & & & & & \\
\hline \multirow[t]{3}{*}{ Sweden (SE) } & 1901-1950 & 0.09 & 79 & 101 & & y & $\mathrm{x}$ & $\mathrm{x}$ & y & $\mathrm{x}$ & & y & & y & \\
\hline & 1951-1990 & 0.40 & 69 & 83 & & $\mathrm{x}$ & $\mathrm{y}$ & $\mathrm{x}$ & $\mathrm{y}$ & $\mathrm{X}$ & & $\mathrm{y}$ & & $\mathrm{Y}$ & \\
\hline & $1991-2012$ & 0.58 & 51 & 69 & & $\mathrm{Y}$ & $\mathrm{X}$ & $\mathrm{Y}$ & $\mathrm{Y}$ & $\mathrm{X}$ & & $\mathrm{X}$ & & $\mathrm{Y}$ & \\
\hline \multirow{3}{*}{$\begin{array}{l}\text { Lower Saxony } \\
\text { (LS) }\end{array}$} & $1901-1950$ & 0.24 & 77 & 96 & $\mathrm{y}$ & $\mathrm{x}$ & & & & & $\mathrm{x}$ & & $\mathrm{Y}$ & $\mathrm{y}$ & \\
\hline & $1951-1990$ & 0.00 & 94 & 120 & $\begin{array}{l}1 \\
\mathrm{y}\end{array}$ & $\mathrm{y}$ & & & & & $\mathrm{x}$ & & $\mathrm{x}$ & $\begin{array}{l}1 \\
\mathrm{y}\end{array}$ & \\
\hline & $1991-2012$ & 0.60 & 52 & 63 & $\mathrm{X}$ & $\mathrm{Y}$ & & & & & $\mathrm{X}$ & & $\mathrm{Y}$ & $\mathrm{Y}$ & \\
\hline The Nether- & $1901-1950$ & 0.13 & 95 & 124 & $\mathrm{x}$ & & y & $\mathrm{x}$ & & $\mathrm{x}$ & & & & $\mathrm{y}$ & $\mathrm{X}$ \\
\hline \multirow{2}{*}{ lands (NL) } & 1951-1990 & 0.39 & 71 & 84 & $\mathrm{x}$ & & $\begin{array}{l}1 \\
\mathrm{y}\end{array}$ & $\mathrm{x}$ & & $\mathrm{Y}$ & & & & $\stackrel{1}{\mathrm{X}}$ & $\mathrm{Y}$ \\
\hline & $1991-2012$ & 0.60 & 54 & 63 & $\mathrm{X}$ & & $\begin{array}{l}\text { I } \\
\mathrm{Y}\end{array}$ & $\mathrm{X}$ & & $\mathrm{Y}$ & & & & $\mathrm{X}$ & $\mathrm{Y}$ \\
\hline \multirow[t]{3}{*}{ Belgium (BE) } & 1901-1950 & 0.00 & 93 & 147 & & & & & & $\mathrm{y}$ & & & & $\mathrm{x}$ & $\mathrm{Y}$ \\
\hline & $1951-1990$ & 0.17 & 83 & 111 & & & & & & $\mathrm{Y}$ & & & & $\mathrm{X}$ & $\mathrm{Y}$ \\
\hline & $1991-2012$ & 0.32 & 79 & 94 & & & & & & $\mathrm{Y}$ & & & & $\mathrm{X}$ & $\mathrm{Y}$ \\
\hline Czech & $1901-1950$ & 0.28 & 85 & 101 & & $\mathrm{Y}$ & & & $\mathrm{y}$ & & & & & & \\
\hline \multirow[t]{2}{*}{ Republic (CZ) } & $1951-1990$ & 0.11 & 88 & 110 & & $\mathrm{Y}$ & & & y & & & & & & \\
\hline & 1991-2012 & 0.24 & 84 & 103 & & $\mathrm{Y}$ & & & $\begin{array}{l}Y \\
\mathrm{Y}\end{array}$ & & & & & & \\
\hline \multirow[t]{3}{*}{ Austria (AT) } & $1901-1950$ & 0.13 & 91 & 132 & $\mathrm{x}$ & & y & $\mathrm{x}$ & & $\mathrm{x}$ & & & $\mathrm{y}$ & $\mathrm{y}$ & \\
\hline & $1951-1990$ & 0.00 & 85 & 105 & $\mathrm{x}$ & & $\begin{array}{l}1 \\
\mathrm{y}\end{array}$ & $\mathrm{x}$ & & $\mathrm{x}$ & & & $\begin{array}{l}1 \\
\mathrm{y}\end{array}$ & $\begin{array}{l}1 \\
\mathrm{y}\end{array}$ & \\
\hline & $1991-2012$ & 0.67 & 49 & 64 & $\mathrm{X}$ & & $\begin{array}{l}1 \\
\mathrm{Y}\end{array}$ & $\mathrm{X}$ & & $\mathrm{Y}$ & & & $\begin{array}{l}1 \\
\mathrm{Y}\end{array}$ & X & \\
\hline \multirow[t]{3}{*}{ Croatia (CR) } & 1901-1950 & 0.36 & 76 & 96 & & & & & y & $\mathrm{y}$ & & & & $\mathrm{X}$ & $\mathrm{Y}$ \\
\hline & 1951-1990 & 0.09 & 93 & 108 & & & & & $\mathrm{y}$ & $\mathrm{Y}$ & & & & $\mathrm{X}$ & $\mathrm{Y}$ \\
\hline & 1991-2012 & 0.32 & 72 & 88 & & & & & $\mathrm{Y}$ & $\mathrm{Y}$ & & & & $\mathrm{X}$ & $\mathrm{Y}$ \\
\hline \multirow[t]{3}{*}{ Tuscany (IT) } & $1901-1950$ & 0.09 & 71 & 91 & & $\mathrm{x}$ & $\mathrm{y}$ & $\mathrm{x}$ & $\mathrm{x}$ & & & & & & \\
\hline & $1951-1990$ & 0.36 & 81 & 103 & & $\mathrm{Y}$ & X & $\mathrm{Y}$ & $\mathrm{Y}$ & & & & & & \\
\hline & 1991-2012 & 0.40 & 74 & 95 & & $\mathrm{X}$ & $\mathrm{Y}$ & $\mathrm{X}$ & $\mathrm{Y}$ & & & & & & \\
\hline \multirow[t]{3}{*}{ Bulgaria (BG) } & 1901-1950 & 0.42 & 69 & 88 & & $\mathrm{X}$ & $\mathrm{Y}$ & $\mathrm{X}$ & & $\mathrm{y}$ & & & & $\mathrm{x}$ & $y$ \\
\hline & $1951-1990$ & 0.22 & 81 & 100 & & $\mathrm{y}$ & $\mathrm{x}$ & $\mathrm{Y}$ & & $\mathrm{y}$ & & & & $\mathrm{x}$ & $\mathrm{Y}$ \\
\hline & $1991-2012$ & 0.57 & 57 & 71 & & $\mathrm{X}$ & $\mathrm{Y}$ & $\mathrm{X}$ & & $\mathrm{Y}$ & & & & $\mathrm{X}$ & $\mathrm{Y}$ \\
\hline \multirow{3}{*}{ All regions } & 1901-1950 & 0.07 & 94 & 131 & $\mathrm{y}$ & $\mathrm{x}$ & $\mathrm{x}$ & $\mathrm{Y}$ & & & & & $\mathrm{Y}$ & & $\mathrm{Y}$ \\
\hline & $1951-1990$ & 0.12 & 91 & 119 & $\begin{array}{l}y \\
\mathrm{y}\end{array}$ & $\mathrm{x}$ & $\mathrm{x}$ & $\mathrm{X}$ & & & & & $\mathrm{x}$ & & $\mathrm{Y}$ \\
\hline & 1991-2012 & 0.15 & 92 & 117 & $\begin{array}{l}Y \\
X\end{array}$ & $\mathrm{X}$ & $\mathrm{Y}$ & $\mathrm{X}$ & & & & & $\mathrm{Y}$ & & $\mathrm{Y}$ \\
\hline
\end{tabular}


Fig. 4. Relationship between adjusted $\mathrm{R}^{2}$ and mean absolute error of the best-fit stepwise regression function between first order differences of climatic variables (see Table 4) and inter-annual yield variations for (a) wheat and (b) barley. Individual dots represent regions listed in Table 4, with triangles showing the results for all regions 
gions, it was not consistent across the periods. Compared to those for wheat, the adjusted $\mathrm{R}^{2}$ values were generally smaller. The sharp decline in the ability of single factors to explain yield variations in the period from 1991-2012 was even stronger for barley than it was for wheat.

\subsubsection{Combined climatic factors}

Combined climatic factors from April-June using the data from 1901-2012 explained a relatively small share of the year-to-year variability in barley yield when all regions were pooled, and their predictive ability was lower than they were for wheat yield (Table 4). Interestingly, no significant relationship was found for Finland, which is likely due to a later harvest occurring in this country (mid- to late August) compared to other regions. For Norway, Lower Saxony and Tuscany, the explained variability in yield was $<10 \%$. Only in the case of Sweden (southern Sweden, where most agriculture is concentrated), the Czech Republic and The Netherlands could $>1 / 5$ of the year-to-year variability be explained by the suite of selected climatic factors over the entire 1901-2012 period. The MAE and RMSE values were similar to those observed for wheat, while the overall influence of climatic patterns appeared to be smaller. For barley, year-to-year yield variations, precipitation totals, number of frost days, daily temperature range and maximum temperatures (all for April-June) seemed to be the most influential of the climatic drivers tested. Similar to the results for wheat, year-to-year increases in precipitation, frost occurrence and maximum temperature from April-June were associated with a decline in barley yield. Short-term droughts seemed to lead to lower yields in Belgium, Croatia and Bulgaria, while long-term droughts in general lowered the overall production level.

Clear evidence of a changing relationship between climatic factors and changes in the yield of barley exist (Table 5). Similar to the observations for wheat, these changes were recorded in northern and southeastern Europe (Norway, Sweden and Lower Saxony compared to Tuscany and Bulgaria). In addition, climatic variables that were able to explain a fairly large portion of the inter-annual yield variability from 1991-2012 showed a much lower predictive ability for the 1901-1950 and 1951-1990 periods. Fig. 4b shows a visible difference in the adjusted $R^{2}$ and RMSE values between the results of the 1991-2012 period and those of the 1901-1950 and 1951-1990 periods, suggesting that the influences of climate on annual crop yields have been changing over the periods considered. It seems that the influence of climatic variables on crop yields has increased in the period from 1991-2012.

\section{DISCUSSION}

While climate plays an important role in limiting the geographical distribution of particular crops (Elsgaard et al. 2012), it also influences overall production levels (see Fig. 3). The low yields generally reported for the 3 most southern regions are from areas where cereal yields are considered to be limited by water availability, heat stress and the short duration of the grain filling period (Ewert et al. 2005). Cereals in these regions are complemented by perennial crops, such as olive, grapes and fruit trees, as they have deeper root systems and can therefore better withstand long dry periods. Crops in this area also tend to be affected by extreme weather events (such as hail and storms) more often, which can reduce or completely destroy the crop in a given year (Olesen et al. 2011). Irrigation is important for crop production in many Mediterranean countries due to high levels of evapotranspiration and limited rainfall. On the other hand, the most productive regions in Europe in terms of climate and soils are located in the Great European Plain, stretching from southeast England through France and Benelux to Germany. In addition to a milder and more favorable Atlantic climate in these regions (see Fig. 1), the more favorable topography should also be considered, which makes the use of highly mechanized agricultural techniques more efficient. These regions also have better supported rural areas, where rural sectors have a history of receiving comparatively higher levels - and/or perhaps better-managed - research and infrastructure investments. Central Europe (represented by the Czech Republic and Austria) has comparatively drier conditions and a greater range of variation in annual temperatures, limiting the range of crops that can be grown and the yields of those that are grown.

Our analyses showed that overall crop production levels can be at least partly attributed to the prevailing climatic conditions (see Fig. 3). This means that the extent of the progress made in increasing yield in the $20^{\text {th }}$ century has been shaped both by the climatic patterns (determining suitability) and by technological and socio-economic changes. For example, wheat and barley yield levels, as well as the rates of their increase, in the Czech Republic and Austria (or Croatia and Italy) were found to be approximately equal 
(comparing results in Fig. 3) despite the fact that these countries, which are similar climatically (as shown in Fig. 1), followed very different paths in their development (see Table 1). In contrast, yield levels in Denmark, Belgium, The Netherlands and Lower Saxony were markedly higher across all time periods analyzed than those of the rest of the group. This is to a great extent attributable to more favorable climatic conditions, because all 4 countries are in the same environmental zone (Atlantic North; Fig. 1a), characterized by mild winters, sufficient and well distributed precipitation and cool summers, among other factors (Metzger et al. 2005). In addition, the overall structure of the farming sector, a relatively fast adoption of modern technologies driven by advanced agricultural research, and past and present investment levels have also supported the attainment of higher yields in these countries than in other countries.

As wheat and barley yields are limited in northern Europe by cool temperatures (Holmer 2008) and in southern Europe by high temperatures and low rainfall (Reidsma \& Ewert 2008) it was hypothesized that the response to warming within these regions is likely to differ. Indeed, in Finland and Norway we found an increasing influence of temperature, and in Bulgaria and Tuscany of drought, after 1951 (Table 5). Somewhat surprisingly, variations in maximum temperature were shown to explain a portion of yield variability only in some northern and northwestern regions (Table 5), which might be explained by the use of cultivars adapted to the high temperatures of the southern regions. However, this adaptation in the choice of varieties planted and in management is likely also to contribute to generally lower yields. A study by Olesen et al. (2011) seems to support this argument, showing that in Finland, a small yield increase has occurred during the last 10-20 yr that is partly linked to increasing temperatures, which has allowed earlier sowing and a prolonged growing season (Rötter et al. 2013, Peltonen-Sainio \& Jauhiainen 2014, Palosuo et al. 2015). On the other hand, the wheat yields in Greece have been declining, which is likely also linked to the increase in temperatures.

The significance of the single variables as presented in Table 4 is likely influenced by the multicollinearity of the individual predictors, and must be interpreted carefully (Farrar \& Glauber 1967). For example, when Tavg is significant and Tmax is not, the significance of Tmax is probably only 'hidden' by the multicollinearity. However, the adjusted $\mathrm{R}^{2}$ values are presented for the whole model and thus the predictability skill of the model is not overestimated. On the other hand, adjusted $\mathrm{R}^{2}$ might even underestimate predictability, as $\mathrm{R}^{2}$ is 'adjusted' by the number of variables, but some variables bring only little new predictive power (because of the multicollinearity). Nevertheless, because of the relatively large number of variables used, the 'adjusted' version of $\mathrm{R}^{2}$ is more realistic that the non-adjusted $\mathrm{R}^{2}$.

Overall, wheat yields in several European countries have been shown to increase in variability, which can be linked to climatic variability (Olesen et al. 2011). The stagnating wheat (and barley) yields across European regions (as depicted in Fig. 3) have been found to be co-determined by the warming climate (Brisson et al. 2010) and/or by changes in management, especially in the changes to fertilization application due to environmental regulations (Finger 2010, Palosuo et al. 2015, Peltonen-Sainio et al. 2015). Gömann et al. (2015) reported that wheat crops have been extended to less favorable sites during the last decades in Germany. Regardless of the cause, post1990 yield variability is, in absolute terms, significantly higher in most of the evaluated regions, while in terms of relative variability (accounting for the increase in mean yield), it remains approximately stable. The higher variability in yields with higher yield levels is coupled to the greater impact of yieldreducing factors, such as elevated temperatures that shorten crop growth durations, or greater water consumption by high-yielding crops that enhance the yield reductions caused by drought (Liu et al. 2013).

In the period from 1991-2012, only the combination of climatic factors, and not any single factor, could explain yield variability to some extent (compare results in Tables $3 \& 5$ ). This indicates that with the changes brought by technological progress, the influence of climate on yields may have become more complex than in the past. This might also signal that the climatic trends are becoming at least as important as the technological trends (e.g. new machinery, better seeds, new cultivars, fertilizers and pesticides) that have dominated European agriculture, especially in the 1951-1990 period (Fig. 3c,d). In addition, other factors, such as soil compaction and reduced soil organic matter content and fertility are important, and may increase the vulnerability of crops to climatic constraints, at least locally (e.g. Peltonen-Sainio et al. 2015). The increasing availability of fertilizers fostered a shift to growing crops in formerly less productive sites (e.g. those with sandy soils), which might have increased the harmful impact of climatic factors. On the other hand, pests and nutrient deficiencies limited crop growth in the earlier periods analyzed here, but have become less important in many regions in recent decades. There 
is at least local evidence that in some regions, agrienvironmental policies and economic challenges faced by farms (e.g. uncertainty over rented lands) have encouraged reduced use of pesticides and nutrients and less balanced crop rotations in recent years, possibly impacting yields and yield variation (PeltonenSainio et al. 2015). Overall yield growth rates across the regions in 1991-2012 were similar to those based on the data from 1901-1950. From a long-term perspective, this constitutes a question of a major importance that should be addressed across Europe.

Although food security in Europe is thought to be less dependent on the climate due to technologically sophisticated agricultural practices (Brown \& Funk 2008), our results indicate that climatic variability still has a significant influence on European wheat and barley productivity. However, the key drivers for changes in productivity differ even within similar environmental regions, and they seem to change with time. Efforts to increase the preparedness of the farmers to adapt to climatic variations are needed, and should result in concrete measures enabling sustainable and more stable food production. This is even more urgent when considering the fact that the present study did not account (due to data constraints) for many types of adverse events that can negatively influence yields. This has been reported for several types of extreme events over recent decades in Germany (Gömann et al. 2015), and a potential increase in the frequency of adverse events was noted by Trnka et al. (2011, 2014, 2015), showing the risk of a several-fold increase in the frequency of events known to lead to decreases in crop yield.

\section{CONCLUSIONS}

This study shows that there is strong (and sometimes counterintuitive) geographical specificity by which factors determine yield variations. For example, while precipitation is amongst the most important factors explaining year-to-year yield changes in Belgium, The Netherlands and Lower Saxony, the indicators of drought variations were found to have only limited explanatory power, even in countries where wheat and barley production is known to be limited by water availability.

It is clear that the influence of climatic variables on yields of wheat and barley has increased in the period from 1991-2012 in most countries. It is important to note that the different set of predictors explained yield variability in this period better than in the periods 1901-1950 and 1951-1990. This leads us to conclude that climate change is altering the sensitivity to particular climatic factors.

Variations in climatic factors (combined together) explained between 18 and $71 \%$ of wheat yield variability and between 5 and $60 \%$ of barley yield variability in the 1991-2012 period. The ability to explain yields based on climatic factors increases (albeit not markedly) when we take into account country-specific time windows, and shows that the April-June period is critical for yield formation of barley and wheat in most of the studied region.

We also conclude that changes in the climate-yield relationships would likely be more easily established over smaller and more homogenous regions than over those for which we were able to collect corresponding data. However, such data are not available - at least not for the countries we analyzed and thus we conclude that the study of climate-yield relationships in Europe is significantly hampered by limited accessibility of agricultural statistics, especially prior to 1961. Despite great effort in collecting data on the 12 European regions studied here, it was difficult to produce a sufficiently complete database on crop yields that covered the period between 19012012, even for the 2 most widely grown crops. As we primarily selected regions that were not significantly affected by changes in borders, the situation in other regions of Europe is likely to be even worse. The lack of an accessible and reliable NUTS4-level yield database for European Union or Europe in general (similar e.g. to the county yield statistics in the USA) hampers not only this type of research activity in Europe, but limits any studies linking the yield of key agricultural products to environmental factors.

Acknowledgements. We thank Heidelinde Trimmel (University of Applied Life Sciences in Vienna) for her support through the historical FAO yearbook search complementing nation based efforts. The paper is the result of a collaboration within the JPI-FACCE MACSUR project and COST ES1106 with its local Czech project no. LD 13030. M.T., P.H., J.B., P.S. and K.R. acknowledge support from the Ministry of Education, Youth and Sports of the Czech Republic within the National Sustainability Program I (NPU I LO1415). M.T. and P.H. were supported by the National Agency for Agricultural Research (project no. QJ1310123) and R.B. by the Czech Grant Agency (project no. 13-19831S).

\section{LITERATURE CITED}

Brisson N, Gate P, Gouache D, Charmet G, Oury FX, Huard F (2010) Why are wheat yields stagnating in Europe? A comprehensive data analysis for France. Field Crops Res 119:201-212

Brown ME, Funk CC (2008) Food security under climate change. Science 319:580-581 
Calderini DF, Slafer GA (1998) Changes in yield and yield stability in wheat during the 20th century. Field Crops Res 57:335-347

Elsgaard L, Børgesen CD, Olesen JE, Siebert S and others (2012) Shifts in comparative advantages for maize, oat, and wheat cropping under climate change in Europe. Food Addit Contam Part A Chem Anal Control Expo Risk Assess 29:1514-1526

Ewert F, Rounsevell MDA, Reginster I, Metzger MJ, Leemans R (2005) Future scenarios of European agricultural land use. I. Estimating changes in crop productivity. Agric Ecosyst Environ 107:101-116

FAO (2006) The state of food insecurity in the world 2006. Food and Agriculture Organization of the United Nations, Rome

FAO (2013) FAO statistical yearbook 2013: world food and agriculture. Food and Agriculture Organization of the United Nations, Rome

Farrar DE, Glauber RR (1967) Multicollinearity in regression analysis: the problem revisited. Rev Econ Stat 49:92-107

Finger R (2010) Evidence of slowing yield growth - the example of Swiss cereal yields. Food Policy 35:175-182

Gobin A (2012) Impact of heat and drought stress on arable crop production in Belgium. Nat Hazards Earth Syst Sci 12:1911-1922

Gömann H, Bender A, Bolte A, Dirksmeyer W and others (2015) Agrarrelevante extremwetterlagen und möglichkeiten von risikomanagementsystemen. Thünen Report 30, Johann Heinrich von Thünen-Institut, Braunschweig

> Harris I, Jones PD, Osborn TJ, Lister DH (2014) Updated high-resolution grids of monthly climatic observations the CRU TS3.10 dataset. Int J Climatol 34:623-642

Hlavinka P, Trnka M, Semerádová D, Dubrovský M, Žalud Z, Možný M (2009) Effect of drought on yield variability of key crops in Czech Republic. Agric Meteorol 149: 431-442

> Holmer B (2008) Fluctuations of winter wheat yields in relation to length of winter in Sweden 1866 to 2006. Clim Res 36:241-252

Kristensen K, Schelde K, Olesen JE (2011) Winter wheat yield response to climate variability in Denmark. J Agric Sci 149:33-47

Liu L, Hu C, Olesen JE, Ju Z, Yang P, Zhang Y (2013) Warming and nitrogen fertilization effects on winter wheat yields in northern China varied between four years. Field Crops Res 151:56-64

Lobell DB, Burke MB (2008) Why are agricultural impacts of climate change so uncertain? The importance of temperature relative to precipitation. Environ Res Lett 3:034007

Lobell DB, Field CB (2007) Global scale climate-crop yield relationships and the impacts of recent warming. Environ Res Lett 2:014002

Lobell DB, Schlenker WS, Costa-Roberts J (2011) Climate trends and global crop production since 1980. Science 333:616-620

Metzger MJ, Bunce RGH, Jongman RHG, Mücher CA, Watkins JW (2005) A climatic stratification of Europe. Glob Ecol Biogeogr 14:549-563

Mitchell TD, Jones PD (2005) An improved method of constructing a database of monthly climate observations and associated high-resolution grids. Int $\mathrm{J}$ Climatol 25: 693-712

Monfreda C, Ramankutty N, Foley JA (2008) Farming the planet. 2. Geographic distribution of crop areas, yields, physiological types, and net primary production in the year 2000. Global Biogeochem Cycles 22:GB1022

Olesen JE, Jensen T, Petersen J (2000) Sensitivity of fieldscale winter wheat production in Denmark to climate variability and climate change. Clim Res 15:221-238

Olesen JE, Trnka M, Kersebaum KC, Skjelvíg O and others (2011) Impacts and adaptation of European crop production systems to climate change. Eur J Agron 34:96-112

Palmer WC (1965) Meteorological drought. Office of Climatology Research Paper 45, US Weather Bureau, Washington, DC

> Palosuo T, Rötter RP, Salo T, Peltonen-Sainio P, Tao F, Lehtonen $H$ (2015) Effects of climate and historical adaptation measures on barley yield trends in Finland. Clim Res 65: 221-236

Peltonen-Sainio P, Jauhiainen L (2014) Lessons from the past in weather: sowing to ripening dynamics and yield penalties for northern agriculture from 1970 to 2012. Reg Environ Change 14:1505-1516

Peltonen-Sainio P, Jauhiainen L, Trnka M, Olesen JE and others (2010) Coincidence of variation in yield and climate in Europe. Agric Ecosyst Environ 139:483-489

> Peltonen-Sainio P, Salo T, Jauhiainen L, Sieviläinen E (2015) Static yields and quality issues: Is the agri-environment program the primary driver? Ambio 44:544-556

Porter JR, Xie L, Challinor AJ, Cochrane K and others (2014) Food security and food production systems. Climate change 2014: impacts, adaptation, and vulnerability. Part A. Global and sectoral aspects. Contribution of Working Group II to the Fifth Assessment Report of the Intergovernmental Panel on Climate Change. Cambridge University Press, Cambridge, p 485-533

> Ramankutty N, Foley JA (1999) Estimating historical changes in global land cover: croplands from 1700 to 1992. Global Biogeochem Cycles 13:997-1027

Ray DK, Ramankutty N, Mueller ND, West PC, Foley JA (2012) Recent patterns of crop yield growth and stagnation. Nat Commun 3:1293

Reidsma P, Ewert F (2008) Regional farm diversity can reduce vulnerability of food production to climate change. Ecol Soc 13:art38

Rötter RP, Höhn J, Trnka M, Fronzek S, Carter TR, Kahiluoto $\mathrm{H}$ (2013) Modelling shifts in agroclimate and crop cultivar response under climate change. Ecol Evol 3: 4197-4214

Slafer GA, Peltonen-Sainio P (2001) Yield trends of temperate cereals in high latitude countries from 1940 to 1998. Agric Food Sci Finland 10:121-131

Slafer GA, Rawson HM (1994) Sensitivity of wheat phasic development to major environmental factors: a re-examination of some assumptions made by physiologists and modellers. Aust J Plant Physiol 21:393-426

Slafer GA, Rawson HM (1996) Responses to photoperiod change with phenophase and temperature during wheat development. Field Crops Res 46:1-13

Solomon S, Qin D, Manning M, Marquis M and others (eds) (2007) Climate change 2007: the physical science basis. Contribution of Working Group I to the Fourth Assessment Report of the Intergovernmental Panel on Climate Change. Cambridge University Press, Cambridge

Stocker TF, Qin D, Plattner GK, Tignor M and others (eds) (2013) Climate change 2013: the physical science basis. Working Group I Contribution to the Fifth Assessment Report of the Intergovernmental Panel on Climate Change. Cambridge University Press, Cambridge 
Trnka M, Dubrovsky M, Svoboda M, Semeradova D, Hayes M, Zalud Z, Wilhite D (2009) Developing a regional drought climatology for the Czech Republic. Int J Climatol 29:863-883

$>$ Trnka M, Olesen JE, Kersebaum KC, Skjelvag AO and others (2011) Agroclimatic conditions in Europe under climate change. Glob Change Biol 17:2298-2318

Trnka M, Brázdil R, Olesen JE, Zahradníček P and others (2012) Could the changes in regional crop yields be a pointer of climatic change? Agric For Meteorol 166-167:

Editorial responsibility: Donald Wilhite (Guest Editor),

Lincoln, Nebraska, USA
$62-71$

Trnka M, Rötter RP, Ruiz-Ramos M, Kersebaum KC, Olesen JE, Žalud Z, Semenov MA (2014) Adverse weather conditions for European wheat production will become more frequent with climate change. Nat Clim Change 4: 637-643

Trnka M, Hlavinka P, Semenov MA (2015) Adaptation options for wheat in Europe will be limited by increased adverse weather events under climate change. J R Soc Interface 12:20150721

Submitted: April 4, 2016; Accepted: August 19, 2016

Proofs received from author(s): October 24, 2016 